\title{
Recruitment, Selection, and Retention of Human Resources in the Implementation of the National Social Economic (Susenas) Sensus Program in the Statistic Center of the Lubuklinggau City
}

Utami Riani Putri ${ }^{1}$, Syamsir $^{2}$

1,2Padang State University, Indonesia

\begin{tabular}{l}
\hline \hline ARTICLE INFO \\
\hline \hline Article history: \\
Received 1 Aug, 2020 \\
Revised 15 Aug, 2020 \\
Accepted 16 Sept, 2020 \\
\hline
\end{tabular}

Keywords:

Recruitment,

Selection,

Retention,

\section{Clonflict of Interest:}

None

Funding:

None
ABSTRACT

This research is motivated by the process of recruitment, selection and retention of human resources in implementing the SUSENAS program at the Central Statistics Agency of the City of Lubuklinggau. The purpose of this study was to determine the process of implementing the SUSENAS program through recruitment, selection, and retention at the Lubuklinggau Central Statistics Agency.This study uses qualitative methods, the informants in this study are BPS employees of Lubuklinggau City, field officers, and the people of Lubuklinggau City, so that the sample obtained in this study amounted to 13 respondents. Data collection techniques in this study are: documentation techniques, and interviews. The data analysis technique used is the SWOT analysis. The results show that development achievements are the main data source for policy makers in planning national development, one of which is through the National Socio-Economic Survey (Susenas) which is the main support for meeting the needs of the government in implementing national development in line with the National Medium-Term Development Plan, to planning, monitoring, and evaluating, as well as measuring the accountability of development and public welfare, namely through the Central Statistics Agency (BPS), is a NonDepartmental Government Institution in Indonesia that has duties based on Presidential Decree No. 103/2001 concerning Position, Duties, Functions, Authority, Organizational Structure, and Work Procedure of non-Departmental Government Institutions, carry out government duties in the field of statistical activities in accordance with the provisions of the applicable laws and regulations. in the process of recruitment, selection and retention on the implementation of the national socioeconomic program in the Lubuklinggau municipal statistics body, the writer can conclude that the Lubuklinggau City Central Statistics Agency seeks qualified, disciplined, and responsible field officers so that the resulting data is of high quality. Constraints encountered in implementing the national socio-economic census program (SUSENAS) on recruitment, selection, and retention of human resources at the Lubuklinggau municipal statistical body are fluctuations where prospective officers who do not meet the needs of the public interest who are less interested in becoming field officers due to lack of promotion from the field of statistics. Central Agency for Statistics of the City of Lubuklinggau.)

Corresponding Author: Utami Riani Putri, Masters in Public Administration, Faculty of Social Science Padang State University. E-mail: utamilinggau123@gnail.com, syamsirsaili@yahoo.com. 


\section{Introduction}

\subsection{Introduce the Problem}

In the era of Sustainable Development Goals (SDGs), Data Revolution, and Big Data as it is now, information on development achievements is the main data source for policy makers in planning national development.

Susenas collects data concerning education, health / nutrition, housing, other socioeconomic, socio-cultural activities, consumption / expenditure and household income and travel. The need for supporting staff who can help government programs, BPS requires partners who will later be tasked with gathering data in each BPS work area, because the vast working area with different respondent characters is the reason BPS needs to recruit partners to be able to assist the work of BPS. In the implementation of the National SocioEconomic Census, open recruitment is carried out by the Lubuklingau Central Statistics Agency and is demanded to be more selective in choosing creative and quality Human Resources because the higher the quality of officers, the higher the accuracy of the data obtained. So that the implementation of measurable and goal-oriented recruitment is possible to get qualified partners / field officers.

From the results of the researchers obtained information about the lack of understanding of the task due to the recruitment of officers bound in a contract for one month, often problems occur such as the resignation of each field officer for various reasons, the accuracy of the results of the data can be influenced by factors in the implementation of non-compliance in the field such as the policy in determining the qualification standards for officers is due to the lack of promotion of the Lubuklinggau City Central Statistics Agency to the public, the community's interest to become a census officer is very poor because the number of officers is not in accordance with the area and geographical location which is difficult to reach as well as the difficulty in achieving places so there is a overlap between target achievement with implementation time so that many officers manipulate data, based on the implementation of the training of prospective census officers not according to the schedule that should be and still lack of supervision and inspector of field officers. For this reason, the recruitment of Susenas officers is done by BPS in Lubuklinggau City by selecting partner officers who are considered to have good performance while serving as BPS partner officers.

\section{Literature Review}

\subsection{Public Policy Implementation}

Meter and Horn (in Winarno, 2002: 102) defines that policy implementation is as actions carried out by government or private individuals (or groups) that are directed to achieve the goals set in previous policy decisions. Thus, the implementation phase occurs only after laws are enacted and funds are provided to finance the implementation of the policy. The actual implementation process not only reveals things that happened after the program was implemented but also includes the choice of implementation models, implementation instruments, implementation strategies and programs with their operations.

\subsection{Concept of Human Resource Management}

Human resource management is a science and art of how to manage the relationships and roles of the workforce to be effective and efficient in helping the achievement of company, employee, and community goals (Hasibuan, 2011). Meanwhile, according to Mathis and Jackson (2011), human resource management is the design of formal organizational systems in ensuring the use of human talent effectively and efficiently to achieve organizational goals. Based on these two understandings it seems clear that the focus in human resource management is the management of talent and the role of human beings effectively and efficiently so that the organization can achieve its goals.

\subsection{Recruitment}

Recruitment can be defined as the process of finding, finding, and attracting applicants to be employed in and by an organization as an initial step to get the right prospective employees to occupy a job.

The aim of Recruitment of Susenas Census field officers is to obtain quality economic condition data that can be used as a foothold in planning and evaluating Indonesia's economic development in general and in the City of Lubuklinggau in particular through qualified officers according to standards from the Central Statistics Agency.

Meanwhile according to Teguh (2009) explains that selection is a process that consists of various specific 
steps from the group of applicants who are the most suitable and meet certain requirements.

There are three things that cause selection to be important, namely:

a. the performance of leaders always depends on the performance of some of their subordinates.

b. Effective selection is important because the recruitment costs incurred by agencies in appointing officers are not small.

c. Good selection is important because of the legal implications of the implementation in a straightforward manner.

\subsection{Employee Retention}

According to Ragupathi (2013), employee retention refers to the techniques used by management to help permanent employees with the organization for a long period of time.

The purpose of employee retention is to retain qualified employees owned by the agency for as long as possible, because qualified employees are intangible assets that are invaluable to the company. From the above understanding, that employee retention is a process in which an agency is able to retain its potential employees to remain loyal to the agency for a longer period of time

\section{Method}

This study is a qualitative study using the Evaluative method, to see how the author can find out Recruitment, Selection and Retention of Human Resources in Implementing the National Socio-Economic Census Progra m (SUSENAS) at the Lubuklinggau City Statistics Agency. Researchers used several data collection techniqu es, including interviews, observation and documentation studies. Interviews are data collection techniques us ed by researchers to obtain verbal information through questions and answers and face to face with people $\mathrm{w}$ ho can provide information to the author. So the writer can gather as much relevant information as possible $\mathrm{w}$ ith a mixture of interviews that have been prepared. Observation (Observation) is a data collection technique through the process of direct observation of objects that are the research theme. Documentation Study is a tec hnique for collecting data and studying written documents and materials and other materials related to researc $\mathrm{h}$ problems in the research object. In this case the writer seeks and studies documents relating to the focus of $\mathrm{t}$ he problem under study, namely Recruitment, Selection, Retention of Human Resources at the Lubuklinggau City Statistics Center.

\section{Results and Discussion}

After conducting research on Recruitment, Selection and Retention of Human Resources in Implementing the National Socio-Economic Census Program (SUSENAS) at the Lubuklinggau City Statistics Agency. So this chapter will describe the findings research findings based on the data description above, obtained a description of the Recruitment, Selection and Retention of Human Resources in the Implementation of the National Socio-Economic Census Program (SUSENAS) at the Lubuklinggau City Central Statistics Agency. Seen from the indicators of Organizational Support, enthusiasm and creativity of the the employee. Then from the factors that influence the Recruitment, Selection and Retention of Human Resources in the Implementation of the National Socio-Economic Census Program (SUSENAS) at the Lubuklinggau City Statistics Agency.

\section{The Recruitment, Selection and Retention Process in Implementing the National Socio-Economic Program} at the Lubuk Linggau City Statistics Agency

The Lubuklinggau City BPS, which has long been established, always strives to maintain its position as a quality BPS that adheres to the values of vision and mission. This survival strategy reflects that the BPS of Lubuklinggau City uses the typology of the defender strategy from Miles and Snow (1978) in Anthony, et al (2006). The recruitment and selection strategy is very important to be owned by the company. This recruitment and selection is the first activity carried out by BPS of Lubuklinggau City in finding HR who will cooperate with it.

\subsection{Requirements for Field Officers}

Susenas field officers consist of supervisors and enumerators. In general, all field workers should meet the following requirements:

1. Minimum high school education (preferably D3 graduates and above);

2. Preferably experienced as a survey / research officer, especially as a Susenas officer

3. Able to work and obey the rules / agreements that have been determined;

\subsection{Recruitment of Officers}


Recruitment is one of the functions of HRM in the aspect of procurement of labor specifically to get prospective employees to be selected which is the best and most in accordance with the required requirements, one of which is through the recruitment process. All of these are the main duties and responsibilities of the HR department. The quality of a company's Human Resources depends on the quality of a recruitment process. According to (Hasibuan, 2007: 40) recruitment as an effort to find and influence prospective workers to want to apply for job vacancies offered by a company. The recruitment of Susenas officers is carried out by BPS in Lubuklinggau City by selecting partner officers who are considered to have good performance while serving as BPS partner officers. All PCL are BPS partners while all PML are BPS organic employees and selected statistical partners who are considered experienced in participating in this activity.

\subsection{Staff Training}

The training in each survey aims to equalize the perceptions of officers towards understanding the concepts and operational definitions of the variables asked in the survey. During the Susenas training, the training began with the Main Instructor Training (Intama), followed by the National Instructor Training (Innas). Both of these activities are carried out at the Center where the executor is the Directorate of People's Welfare Statistics. Henceforth, Innas will immediately train field officers (enumerators and supervisors) to be carried out in each district / city. In staff training, the main things taught are understanding of survey activities, concepts / definitions used, and the ability to transfer the knowledge that has been obtained to prospective officers. Whereas in the training of field staff, the emphasis is more on understanding concepts / definitions, understanding survey procedures, and understanding filling in the list, and will be added material on updating, exercises on how to fill out questionnaires, and interview exercises. In each training process there are three things that must be achieved:

1. Every trainee must read and understand the contents of the questionnaire to be used;

2. Every trainee must read and understand the concept definitions contained in the manual;

3. Each trainee must understand how to interview and fill in the results of the interview into the questionnaire.

Innas Training was held for 3 (three) effective days in 2 waves. The training participants came from the Regional BPS. Innas candidates are expected to meet the following requirements:

a) Minimum D3 education (statistics);

b) Preferably from the Provincial BPS Social Statistics Sector or Regency / City BPS Social Statistics Section;

c) Having experience in Susenas activities,

d) Have the ability to teach;

e) Ready to solve cases that arise in the field implementation.

\subsection{Susenas Officer Selection Process}

Selection is the first effort a company must make to obtain qualified and competent employees who will serve and do all the work at the company. Presumably this is what drives the importance of the implementation of new recruitment selection for each company. The selection must be carried out honestly, carefully and objectively so that the employees who are accepted are truly qualified to hold the position and do the work. (Hasibuan 51-52) According to Ambar T Sulistiyani and Rosidah the selection is a series of steps taken to decide whether an applicant is accepted or rejected, in a particular institution after undergoing a series of tests carried out. Selection is also referred to as an activity of selecting and determining applicants who are accepted or rejected to become employees of the company (Hasibuan 2007: 177). The following is the elaboration of the existing tests according to the author's research results:

\section{a. Administration}

The first stage carried out was administrative selection. This selection is a selection to sort the prospective employee file in accordance with existing standards. In BPS the City of Lubuklinggau also has several aspects that were seen when conducting administrative selection. From these findings, BPS in Lubuklinggau City applied a more or less similar administrative selection to the agencies in general. The officer selection begins with an examination of the completeness of the application file, which includes: application letter, photocopy of diploma, photocopy of KTP, photocopy of NPWP (who has) and permission from superiors (for those who are already working) and registration forms. Judging from his education, those who passed 
stage 1 were mostly high school graduates (49.31 percent). While those who graduated from Bachelor program were 43.93 percent and those from postgraduate level were 0.61 percent. The next test is a written test and an interview test, a written test takes approximately 15 minutes and an interview test of 10-15 minutes.

b. Written selection

Written selection is the next test after the prospective employees successfully pass administrative selection. Written test to see the extent of knowledge about SUSENAS and the mathematical ability of prospective officers, bearing in mind that in the SUSENAS listing the officer will have to obtain information about the income and expenses of each business.

\section{c. Interview Selection}

The next selection is interview selection. This selection is done to better find out which candidate is the best. Someone can be good at writing, but when faced with an interview test is not as good as in writing. While the interview test is to see commitment, sincerity, willingness to work across sub-districts and the ability to manage time to finish on time.

\subsection{Final decision}

The length of the series of selection stages ends with the final decision on acceptance. At the selection stage that has been carried out, each examiner has revealed the results of the assessment. The results or points that have been collected into one recap will be taken to the public service for compilation. When all the points have been recapitulated, a plenary session is held. The plenary session was attended by all recruitment and selection teams to discuss the results. In implementing the recruitment and employee selection strategy, BPS in the City of Lubuklinggau has a certain policy, namely the use of recruitment sources from new field officers and field officers who have experience. The existing implementation has experienced several changes compared to a few years ago. In its implementation, BPS of the City of Lubuklinggau when open vacancies, both external and internal are free to register. There is no difference between the two in the recruitment and selection process.

\subsection{Retention Process}

The definition or understanding of employee retention is often interpreted as an effort to retain employees in the organization. Employee retention refers to various policies and practices that direct employees to stay in the organization for a longer period of time. Each organization invests time and money into developing new recruitment so that it is ready to work and can match existing employees. Therefore also, losing employees always means losing knowledge, capital, expertise, and experience. If the organization loses someone with a lot of knowledge and is trained, basically the organization has lost the income that the employee should have generated.

Based on the definition above, it is necessary to develop measures that can maintain existing human resource assets in the organization. In principle, the greater the employee feels the organization where he works to develop a human resource policy that is centered on professional welfare, the less the employee's tendency to leave the organization that employs them. The higher employee satisfaction with working conditions in the organization, the less likely an employee is to leave the organization. Thus, the retention process carried out by the city of Lubuklinggau BPS on field employees which is only contacted for one month a year and for those who are willing to continue the following year with good performance, the opportunity for them to be re-recruited is very large on the grounds they already have experience.

2. Constraints encountered in the Recruitment, Selection and Retention of Human Resources in Implementing the National Socio-Economic Census Program (SUSENAS) at the Lubuklinggau City Statistics Agency?

Based on the results of research conducted by researchers in this case will be discussed related to what are the obstacles that exist during the recruitment and selection process BPS Lubuklinggau City.

\subsection{Fluctuation}

The number of applicants so that the emergence of obstacles in the process of recruitment, selection and retention in the implementation of the SUSENAS program such as candidates for officers who are not in accordance with needs cannot be avoided if during the recruitment process there will be times when the number of applicants exceeds expectations or even very less than expected expectations. When the number of applicants is large and exceeds expectations, of course BPS will get many candidates to be selected. However, when it is lacking, BPS will find it difficult to continue the selection process and ultimately retain 
the old partner or field officers.

2.2. Recruitment and selection procedures that are used will spend a lot of time and money

The use of existing costs must adjust to a predetermined budget so that the possibility for them to get compensation is very small. costs used must be re-evaluated as reference material for further implementation. Pearce et al. (2009) state that there are 9 critical tasks, one of which is the evaluation of the success of the strategy process as an input for future policy making. Same as what was done by BPS Lubuklinggau City which made evaluation as a consideration for the next strategy.

2.3. Recruitment of partner employees who have not been good, most of the level of education of partners who have not met the specified standards

This is due to the low public interest in registering himself as a field officer so that the applicant is just that person and the level of education of applicants is more high school.

2.4. Comparison of the number of field officers with workloads that are still not optimal so that the quality of human resources is still weak.

Based on the manual, a field officer is in charge of updating and census an average of 2 census blocks. For Lubuklinggau City a field officer is in charge of updating and enumerating 2 census blocks. But in reality the workload is not in accordance with the guidelines, in the field one officer gets 3 - 4 blocks with a geographical condition that is not strategic, the placement of officers that is not in accordance with the area so that becomes an obstacle for them.

\subsection{Lack of coordination between BPS and partner officers}

Coordination is a process of synergy and balance of all activities in the work between one party and another in order to achieve a common goal. In that way, coordination is also a process of mutual understanding and understanding between two or more parties in carrying out a matter. In this case throwing responsibility at each other, because each of them feels that an authority or field of work is not included in its scope. Like BPS, which has entrusted all to the supervisor and the supervisor has trusted the officers to carry out their duties so that it is probable that the field officers manipulated the data due to deadline reasons.

2.6. Limited Officers use Science and Technology

With the advancement of technology in this day and age science and technology is very much needed in daily life, which is an obstacle for BPS in the city of Lubuklinggau is because of the interest of the community to become field officers and their level of education is an average high school graduate, for the use of gadjet or for online devices they find it difficult to use it.

3. How to formulate strategies in overcoming obstacles in the Recruitment, Selection and Retention of Human Resources in Implementing the National Socio-Economic Census Program (SUSENAS) at the Lubuklinggau City Central Statistics Agency.

SWOT Analysis of Recruitment, Selection and Retention of Human Resources in the Implementation of the National Socio-Economic Census Program (SUSENAS) at the Lubuklinggau City Central Statistics Agency.

1. Strength Analysis (Strerghs)

Based on the quality found, it is bound by the policy of Implementing the National Socio-Economic Census Program (SUSENAS) on Recruitment, Selection, and Retention of Human Resources at the Lubuklinggau Municipal Statistics Agency. There are several strengths of the policy of implementing the National SocioEconomic Census Program (SUSENAS) on Recruitment, Selection, and Retention of Human Resources at the Lubuklinggau Municipal Statistics Agency.

a. The procedure is different from last year because BPS of Lubuklinggau City has aligned the needs of field officers to create guidelines for the Implementation of the National Socio-Economic Census Program (SUSENAS) on Recruitment, Selection, and Retention of Human Resources at the Lubuklinggau City Statistic Agency and other policies.

b. To improve the ability of survey workers, training is conducted prior to the implementation of the field enumeration.

c. Conduct supervision and personal approach with authorized personnel to fill in the questionnaire

d. Optimizing existing resources through retention (retaining old field officers)

e. Having a conducive work environment every prospective officer wants to get a conducive friendly work 
environment supporting each other.

\section{Weaknesces Analysis}

a. BPS coordination and cooperation with partner officers' recruitment of partner officers who have not been good, the level of education of partners who have not met the specified standards.

b. Recruitment of partner officers who do not yet meet the qualifications, the level of education of partners who meet the standards set.

c. Comparison of the number of field officers with workloads that are still not optimal so that the quality of understanding of enumeration / data collection activities by officers is still weak and inadequate.

d. Limited field workers in using science and technology

\section{Opportunity Analysis}

a. Opportunities for all Lubuklinggau municipal communities to open up to become Susenas field officers

b. Open opportunities for old Susenas field officers to be recruited and reselected.

\section{Threats Analysis}

a. The emergence of obstacles in recruitment, selection, retention such as prospective officers who are not according to needs.

b. Recruitment and selection procedures that are used will spend a lot of time and money.

\section{Conclusuion}

\section{A. Conclusion}

Based on the research results, the following research conclusions are obtained:

1. In the process of recruitment, selection and retention in the implementation of the national socioeconomic program in the Lubuk linggau city statistics agency, the writer can conclude that recruitment starts from using internal recruitment sources, namely from old and external field officers by opening opportunities to anyone who is qualified to register himself as a prospective SUSENAS field officer. In recruitment also uses mass media, websites, social media and information from family and close friends. In the selection process, there are several stages that must be passed by the applicants, namely: administrative selection, written test, interview test and final decision.

2. Obstacles encountered in the Recruitment, Selection and Retention of Human Resources in Implementing the National Socio-Economic Census Program (SUSENAS) at the Lubuklinggau City Central Statistics Agency. These are fluctuations where prospective officers who do not meet the needs of the public are not interested in becoming field officers so that BPS The city of Lubuklinggau finally retains the old partner or field officers, the recruitment and selection procedures used will take a lot of time and money so that there is no compensation or bonuses received by the field officers. Comparison of the number of field workers with workloads that are still not optimal so that the quality of its human resources is still weak, Lack of coordination between BPS and partner officers, and the Limitations of Officers using Science and Technology.

3. Formulate strategies in overcoming obstacles in the Recruitment, Selection and Retention of Human Resources in the Implementation of the National Socio-Economic Census Program (SUSENAS) at the Lubuklinggau City Central Statistics Agency. through the SWOT analysis it is found that there are several strengths in the implementation of the SUSENAS program. The procedure is different from last year because BPS of the City of Lubuklinggau has aligned the needs of field officers to make guidelines for implementing the national socio-economic census program (susenas) on recruitment, selection and resource retention. human at the statistical center of the city of Lubuklinggau. And other policies, To improve the ability of survey officers, conduct training before conducting field enumerations, conduct supervision and personal approach with authorized officials to fill in the questionnaire, optimizing available resources through retention, having a working environment condisive. Then obtained weaknesses of coordination and cooperation between BPS and partner officers, recruitment of partner officers that have not been good, the level of education of partners who have not met the specified standards, the recruitment of partner officers who have not met the qualifications, the level of education of partners who meet the specified standards, comparison of the number of field officers with workloads that are still not optimal so that the quality of understanding enumeration / data collection activities by officers is still weak and inadequate, the limitations of field staff in using science and technology then the opportunity for opening opportunities for all Lubuklinggau city people to become Susenas field officers, opening opportunities for Susenas field officers a 
long time to be recruited and reselected. Continuing challenges from this program the emergence of recruitment, selection, and retention constraints such as prospective officers who do not meet the needs, the recruitment and selection procedures used will incur no time or money. $\mathrm{k}$ little. Therefore the strategy is offered by the author, namely Aligning Needs, Guidelines, and Policies, Searching and Screening of Superior Persons, Superior, Reappraisal for Improvement, Quality Improvement of SUSENAS Officers.

\section{Acknowledgements}

\section{Suggestion}

Seeing the conditions on the ground, it shows that there are still obstacles in the implementation of Public Services through the Padang Pariaman Licensing Shuttle Program (AJEP PAPA) in Padang Pariaman District. The authors suggest: 1) It is hoped that all offices associated with the Padang Pariaman Licensing Shuttle Program will hold a joint meeting once a month for communication and supervision of the Padang Pariaman Licensing Shuttle Program. 2) It is hoped that the Industrial Services and Integrated Investment Services Office will better inform and socialize the existence of the Padang Pariaman Licensing Shuttle Program to the public. So that the public knows later and can increase community participation in permit management through the Licensing Shuttle Program. 3) It is hoped that the regional government can budget more for the Integrated Industrial and Investment Service Office to complete the facilities and infrastructure and to increase existing and maximum resources. because remember the reason why this program was welcomed by the wider community and had a positive impact on the community and also had a positive impact on increasing Local Revenue

\section{References}

Basrowi \& Kelvin. 2008. Understanding Qualitative Research. Jakarta: PT Rineka Cipta.

Bangun, W. (2012). Human Resource Management. Jakarta: Erlangga.

Burhan Bungin. 2012. Qualitative Research Methods. Jakarta: PT Rineka Cipta.

Darsono and Siswandoko. (2011). 21st Century Human Resource Management. Jakarta: Nusantara Consulting.

Dwiyanto Indahono. 2009. Public Policy (Based on Dynamic Policy Analysis). Yogyakarta: Gava Media.

Harbani Pasolong. 2010. Public Administration Theory. Bandung: Alfa Beta.

Hasibuan, Melayu S.P. 2001. Human Resources Management Jakarta Revised Edition: PT Bumi Aksara.

Mathis, Robert L. And Jackson Jhon H. 2011. Human Resources Management. Jakarta: Salemba Empat.

Maleong, Lexi J. 2010. Qualitative Research Methods. Bandung: PT Youth Rosdakarya.

Muhammad Idrus. 2009. Social Sciences Research Methods (Qualitative and Quantitative Approaches) Second Edition. Yogyakarta: Erlangga.

Robbins, S.P. (2003). Organizational behavior. Jakarta: PT. Gramedia Index.

Riant Nugroho. 2009. Public Policy. Jakarta. PT. Elex Media Kompitindo.

Samsudin, S. 2006. Human Resource Management. PT Pustaka Setia, Bandung.

Siagian, Sondang P., 2006. Human Resource Management. Bumi Aksara, Jakarta.

Simamora, H. 2004. Human Resource Management Edition III. YKPN College of Economics, Yogyakarta.

Sugiyono 2012. Understanding Qualitative Research. Bandung: Alfabeta.

2014. Qualitative and Combined Research Methods (Mixed Methods). Bandung: Alfabeta.

Suharsimi Arikunto \& Cepi Safruddin, Abdul Jabar. 2010. Evaluation of Educational Programs (Practical Theoretical Guidelines for Students and Educational Practitioners). Jakarta: Earth Literacy.

Sutrisno, E. 2009. Human Resources Management. Jakarta: Kencana

Susilo, A. (2013). Effect of Employee Retention and Customer Satisfaction on Performance. Journal of Accounting and Business Studies, 251, Vo. 1 No. 3 (accessed on 6 November 2018)

Sumarni, Murti. 2011. The Effect of Employee Retention on Trunover Intention and Employee Performance. Akmenika UPY Vol. 8 (accessed on 7 November 2018) 